профессор, академик НАAН Украины, заведующий кафедрой административного менеджмента и альтернативных источников энергии, Винницкий национальный аграрный университет (21008, г. Винница, ул. Солнечная, 3, e-mail: rector@ vsau.org).

ШИНЬКОВИЧ Андрей Васильевич - соискатель, ассистент кафедры финансов, банковского дела и страхования, Винницкий национальный аграрный университет (21008, г. Винница, ул. Солнечная, 3, e-mail: shinkovich7@gmail.com).

УДК: 005.91:620.91:711.437:631.115.8

DOI: 10.37128/2411-4413-2020-1-2

ДОСВІД ФОРМУВАННЯ ЕНЕРГЕТИЧНОї АВТОНОМІї СІЛЬСЬКИХ ТЕРИТОРІЙ: ОЩНКА РОЛІ КООПЕРАТИВІВ
ГОНЧАРУК І.В.,
кандидат економічних наук, доцент
кафедри економіки,
проректор з наукової та
інноваційної діяльності,
Віннццький національний
аграрний університет

(м. Вінниця)

У публікащії розглядаються питання змін клімату, викликані викидами від використання викопних видів палива. Установлено, щзо швидкість підвищення температури : повітря в Украӥні випереджає світові тенденції, внаслідок чого в Украӥні ймовірне посилення та поширення посух, збільшення площ земель, схильних до опустелювання. Досліджено вплив збільшення частки альтернативних видів палива у загальному обсягу виробництва енергії на зменшення викидів парникових газів у світі. Проаналізовано обсяги споживання електроенергї побутовими $i$ не побутовими споживачами та зростання иін на них; чисельність населення України та стан зайнятості сільського населення. Запропоновано вирішити проблеми зі зменшенням тягаря оплати за енергоресурси і створення нових робочих місиь у сільських територіях за рахунок створення енергетичних кооперативів. Висвітлено визначення поняття «енергетичний кооператив» та запропоновано економічні моделі. енергетичних кооперативів, щуо можуть застосовуватись украйнськими територіальними громадами та господарюючими структурами задля забезпечення енергетичної автономії. $У:$ статті проаналізований досвід створення та функиіонування енергетичних кооперативів у краӥнах-членах $6 C$, США та інших країнах світу за такими ознаками: сферою діяльності; формою власності; джерелами фінансування; сочіальним ефектом та іншими. Наведено приклади успішного функиіонування та зародження енергокооперативів в украӥнських громадах, які забезпечують енергетичну автономію окремих підприємств аграрного сектору $\mathfrak{\sim}$ та жителів громади за рахунок виробництва палива з відходів сільського та лісового: господарства; запуску сонячної чи вітрової електростаниії, що продає електрику у мережу ї за «зеленим» тарифом; виробництва біогазу з біомаси; виготовлення та використання сонячних водонагрівачів тощьо. Сформульоване авторське бачення основних напрямів

${ }^{2}$ ГОНЧАРУК I.B., 2020 
розвитку декарбонізаџії економіки.

Ключові слова: енергетичний кооператив, відновлювані джерела енергії, електроенергія, декарбонізація економіки, сільські території.

Рис.: 3. Табл.: 2. Літ.: 17

\title{
EXPERIENCE OF FORMING OF ENERGY AUTONOMY IN RURAL AREAS: ASSESSING THE ROLE OF COOPERATIVES
}

\author{
HONCHARUK Inna, \\ PhD in Economics, \\ Associate Professor, Department of Economics, \\ Vice-Rector for Science and Innovation Activity, \\ Vinnytsia National Agrarian University \\ (Vinnytsia)
}

The publication addresses climate change issues caused by fossil fuel emissions. It is established that the rate of increase of the air temperature in Ukraine is ahead of the world tendencies, as a result of which in Ukraine the widespread of droughts, an increase in land areas prone to desertification is probable. The effect of increasing the share of alternative fuels in total energy production on reducing greenhouse gas emissions in the world has been investigated. The volume of electricity consumption by household and non-household consumers and the price increase for them are analyzed; population of Ukraine and employment status of rural population. It is proposed to solve the problems of reducing the burden of payment for energy resources and creating new jobs in rural areas through the creation of energy cooperatives. The concept of "energy cooperative" is defined and economic models of energy cooperatives that can be applied by Ukrainian territorial communities and economic structures to ensure energy autonomy are proposed. The article analyzes the experience of setting up and operating energy cooperatives in the EU Member States, the USA and other countries of the world on the following grounds: field of activity; the form of ownership; sources of financing; social effect and others. Examples of successful operation and emergence of energy cooperatives in Ukrainian communities are provided, which provide energy autonomy for individual agricultural enterprises and community residents through the production of fuel from agricultural and forestry waste; launching a solar or wind power plant that sells electricity to the grid at a "green" rate; biogas production from biomass; production and use of solar water heaters and the like. The author's vision of the main directions of development of economic decarbonisation is formulated.

Keywords: energy cooperative, renewable energy sources, electricity, decarbonisation of the economy, rural areas.

Fig.: 3. Tabl.: 2. Ref.: 17

\section{ОПЫТ ФОРМИРОВАНИЯ ЭНЕРГЕТИЧЕСКОЙ АВТОНОМИИ СЕЛЬСКИХ ТЕРРИТОРИЙ: ОЦЕНКА РОЛИ КООПЕРАТИВОВ}

ГОНЧАРУК И.В., кандидат экономических наук, доцент кафедры экономики, проректор с научной и инновационной деятельности, Винницкий национальный аграрный университет 
В публикации рассматриваются вопросы изменения климата, вызванные выбросами от использования ископаемых видов топлива. Установлено, что скорость повышения температуры воздуха в Украине опережает мировые тенденции, в результате чего в Украине возможно усиление и распространение засух, увеличение площадей земель, подверженных опустыниванию. Исследовано влияние увеличения доли альтернативных видов топлива в общем объеме производства энергии на уменьшение выбросов парниковых газов в мире. Проанализированы объемы потребления электроэнергии бытовыми и не бытовыми потребителями и рост иен на них; численность населения Украины и состояние занятости сельского населения. Предложено решить проблемы с уменьшением бремени оплать за энергоресурсы и создание новых рабочих мест в сельских территориях за счет создания энергетических кооперативов. Дано определение понятия «энергетический кооператив» $u$ предложень экономические модели энергетических кооперативов, которые могут применяться украинскими территориальными общинами и хозяйствующими структурами для обеспечения энергетической автономии. В статье проанализирован опыт создания $u$ функиионирования энергетических кооперативов в странах-членах EC, США и других странах мира по следуюшим признакам: сферой деятельности; формой собственности; источниками финансирования; социальным эффектом и другими. Приведены примеры успешного функиионирования и зарождения енергокооперативов в украинских общинах, 吉. которые обеспечивают энергетическую автономию отдельных предприятий аграрного сектора и жителей общины за счет производства топлива из отходов сельского и лесного хозяйства; запуска солнечной или ветровой электростанции, которая продаёт электричество в сеть по «зеленому» тарифу; производство биогаза из биомассы; изготовления и использования солнечных водонагревателей и пр. Сформулировано авторское видение основных направлений развития декарбонизации экономики.

Ключевые слова: энергетический кооператив, возобновляемые источники энергии, электроэнергия, декарбонизация экономики, сельская месность.

Рис.: 3. Табл.: 2. Лит.: 17

Постановка проблеми. У світі відбуваються інтенсивні зміни клімату, викликані викидами від використання нафти, газу та вугілля. Для попередження. зміни клімату необхідно різко скоротити викиди парникових газів. В Україні для цього необхідно підвищувати ефективність використання енергії та замінювати викопні ресурси відновлюваними джерелами енергії (сонце, вітер, біомаса). Це економічно вигідно уже зараз, особливо на рівні громад.

Одним iз перспективних напрямків розвитку громад $\epsilon$ створення енергетичних кооперативів. Такі кооперативи залучають пайові внески від мешканців, комунальних підприємств, бізнесу чи будь-яких інших фізичних $\mathrm{i}$ юридичних осіб для створення прибуткових підприємств, що використовують місцеві енергетичні ресурси. Власники паїв отримують частку прибутку, громада - забезпечення новими робочими місцями, надходженнями до бюджету $\mathrm{i}$ енергетичними ресурсами, які забезпечуватимуть енергетичну автономію: конкретних сільськогосподарських підприємств і громади вцілому.

Аналіз останніх досліджень і публікацій. Поліпшення стану довкілля в. Україні; створення еколого-економічних умов для збалансованого сталого ふ্ঞ розвитку держави; гарантування екологічної безпеки, збереження біорізноманіття; формування умов для відтворення природних ресурсів; підвищення ресурсо- та енергоефективності економіки та розроблення 
рекомендацій щодо комплексного розв'язання екологічних проблем за рахунок інноваційного розвитку галузі виробництва біопалива розглянуто в працях вітчизняних вчених Калетніка Г.М., Гончарук Т.В. [16].

Шпикуляк О.Г., Іванченко В.О. [9], Пантелеймоненко А.О., Грицюк Т.І. здійснили теоретико-методичну оцінку та охарактеризували засади розвитку енергетичних кооперативів Німеччини, що виробляють екологічно чисту енергію з відновлюваних джерел, і запропонували шляхи адаптації цього досвіду до реалій України.

Кузьміна М. [8] дослідила особливості правового регулювання створення та функціонування енергетичних кооперативів, а Байко Р. [10] у своїх публікаціях висвітила вимоги німецького та австрійського законодавства щодо правового та організаційного статусу енергетичних кооперативів, зокрема їх заснування, організації діяльності та відповідальності. У публікації проаналізовано також державні гарантії діяльності енергетичних кооперативів, - правила ліцензування їх діяльності та надання їм державної і місцевої підтримки.

Коссе I. [11], Зінченко А., Скляров Р., Бондарчук I. [13] навели приклади успішно реалізованих проєктів кооперативів у галузі альтернативної енергетики, які забезпечують енергетичну автономію суб'єктів господарювання, жителів територіальних громад та соціально-економічний розвиток сільських територій.

Серед зарубіжних вчених цю тематику досліджували Верлінг А., Шваншез В., Зейб Дж., Боут С. та інші [12].

Поряд із цим, незважаючи на наявність наукових публікацій iз відповідного напряму, їхня кількість незначна, а питання розвитку організаційних структур сприяння енергетичній автономії сільських територій досліджено недостатньо та потребує подальшого вивчення.

Мета статті. Охарактеризувати досвід формування енергетичної автономії сільських територій, здійснити оцінку ролі кооперативів у іiі забезпеченні.

Виклад основного матеріалу. За останні два десятиріччя питання щодо зміни клімату перетворилося в одну 3 найбільш гострих проблем світової економіки і політики у контексті вироблення стратегій скорочення викидів парникових газів і поступового переходу до низьковуглецевого розвитку всіх секторів економіки і складових життєдіяльності людини.

Сьогодні наслідки зміни клімату вже відчуваються i вони посилюватимуться у майбутньому. Зміна клімату ніколи не була такою стрімкою, як за останні 30 років. Останні чотири роки у світі - найжаркіші за всю історію метеорологічних спостережень за погодою. Паризька Угода закріплює показник $+2{ }^{\circ} \mathrm{C}$, як верхню допустиму межу підвищення глобальної температури і закликає всі країни докласти значних зусиль, щоб не перевищити зростання глобальної температури понад $+1,5^{\circ} \mathrm{C}$.

Швидкість підвищення температури повітря в Україні випереджає світові тенденції, внаслідок чого в Україні ймовірне посилення та поширення посух, збільшення площ земель, схильних до опустелювання. Відбувається стійке підвищення температури повітря у всі сезони. В Україні середня річна 
температура підвищилася на $1,2{ }^{\circ} \mathrm{C}$.

В Україні посилюється тенденція до нерівномірного розподілу опадів упродовж року, що призводить до більшої кількості та інтенсивності надзвичайних явищ погоди (зокрема, паводків та посух). У 10 областях України за період 2014-2018 рр. опадів випало на 7-12\% менше норми. Спостерігається тенденція до збільшення території із недостатньою кількістю опадів. Клімат вже став більш посушливим на всій території України. Останніми роками посухи спостерігалися в районах, в яких їх раніше не було.

Основною причиною зміни клімату є людська діяльність - збільшення використання вугілля, нафти, газу, промислові процеси і зменшення площ лісів.

Якщо людство не відмовиться від використання викопного палива в другій половині століття, то вже через 30 років середня річна температура в Україні може підвищитися ще на $1-1,5 \mathrm{C}$, а до кінця століття на $3,4-4^{\circ} \mathrm{C}$ [17].

За даними Міжнародної енергетичної агенції (International Energy Agency), загальний обсяг емісії викидів $\mathrm{CO}_{2}$ у світі невпинно зростає. У 2017 році у світі він становив $32840 \mathrm{Mt}$ of $\mathrm{CO}_{2}$, у США - $4761 \mathrm{Mt}$ of $\mathrm{CO}_{2}$, країнах $\mathrm{CC}-3209 \mathrm{Mt}$ of $\mathrm{CO}_{2}$ (мегатон еквіваленту $\mathrm{CO}_{2}$ ). Серед країн Свропейського Союзу найбільша частка викидів припадає на Німеччину $-719 \mathrm{Mt}$ of $\mathrm{CO}_{2}$, Францію - $306 \mathrm{Mt}$ of $\mathrm{CO}_{2}$, Італію - $321 \mathrm{Mt}$ of $\mathrm{CO}_{2}$, Іспанію - $253 \mathrm{Mt}$ of $\mathrm{CO}_{2}$ В Україні ж обсяг емісії викидів $\mathrm{CO}_{2}$ у 2017 році становив $171 \mathrm{Mt}$ of $\mathrm{CO}_{2}$ (мегатон еквіваленту $\mathrm{CO}_{2}$ ) (рис. 1) [5].

У більшості країн світу борються зі скороченням викидів вуглекислого газу. Урядами країн СС прийняті так звані плани кліматичних змін, згідно з якими до 2030 року людство мусить наполовину скоротити викиди парникових газів, а у 2050 році не мати їх зовсім.

Для прикладу, відповідно до затвердженого німецьким урядом Плану кліматичних заходів (Climate Action Plan 2050) до 2050 року, здійснена оцінка наявних кліматичних сценаріїв та аналіз трансформації, визначені загальні цілі, 气̆ принципи, основні етапи та заходи трансформації у кожній області економіки країни: енергетиці, будівництві, транспорті, промисловості, сільському господарстві та інших. Загальні викиди парникових газів Німеччини до 2030 року повинні бути зменшені щонайменше на 55\% порівняно з 1990 роком (референтне значення: загальна кількість викидів $\mathrm{CO}_{2}$ в еквіваленті 1248 млн тонн) [7].

Збереження екосистем можливе за рахунок зменшення викидів парникових газів шляхом заміни викопних видів палива, відновлюваними джерелами енергії.

За даними Євростату, частка відновлюваних джерел енергії у загальному енергетичному балансі країн-членів СС з 2004 по 2018 роки збільшилась майже вдвічі. У 2018 році у Швеції більше половини (54,6\%) енергії у валовому кінцевому споживанні енергії, вироблялось із відновлюваних джерел, Фінляндії ঞ - 41,2\%, Латвії - 40,3\%, Данії - 36,1\% та Австрії - 33,4\%. Серед країн-членів ССiз найменшою часткою відновлюваних джерел енергії в енергетичному балансі $\epsilon$ Нідерланди (7,4\%), Мальта (8,0\%), Люксембург (9,1\%) та Бельгія (9,4\%). До 2020 
року ЄС прагне досягти $20 \%$ валового кінцевого споживання енергії 3 поновлюваних джерел, а деякі країни вже перетнули цю межу [6].

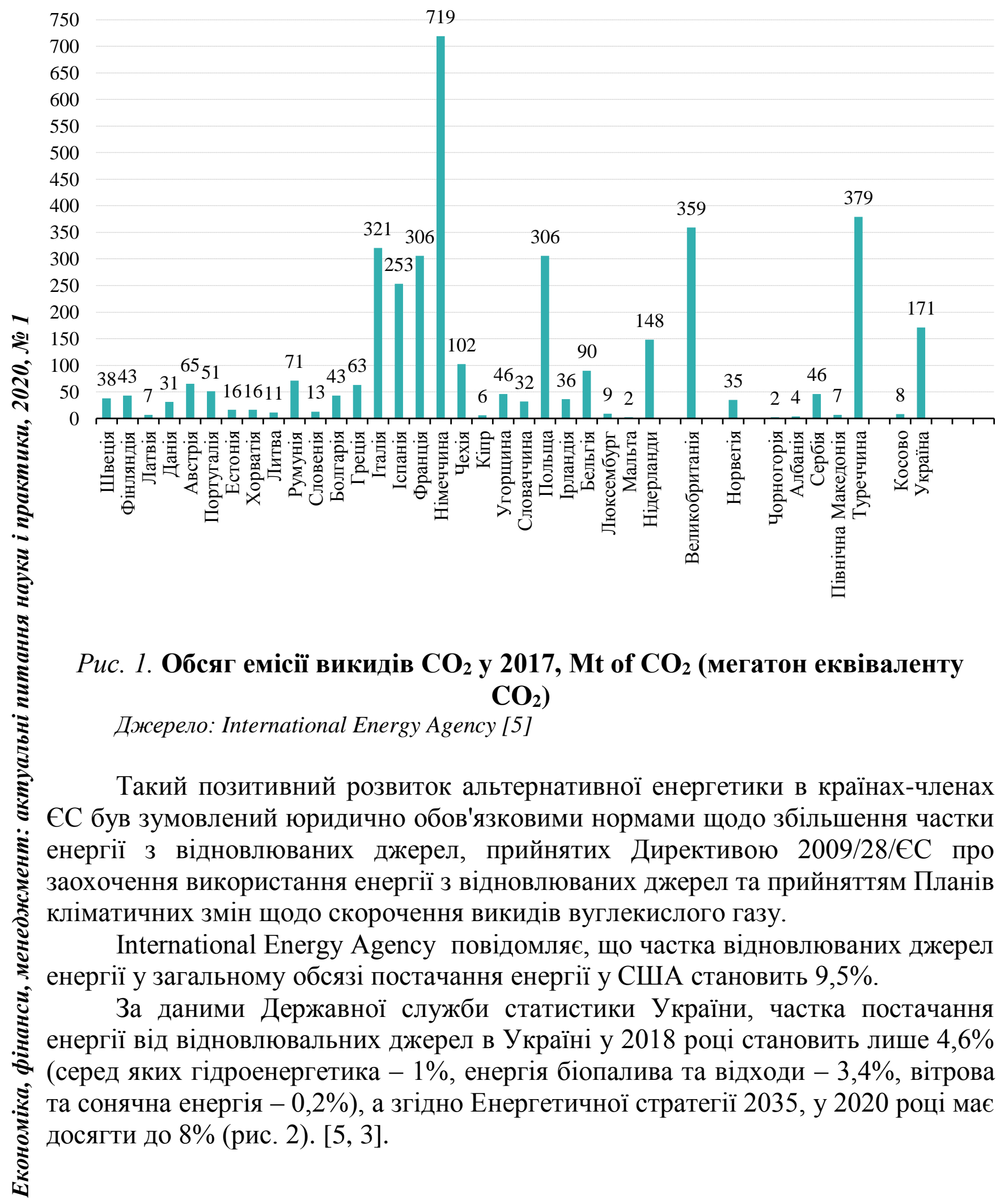




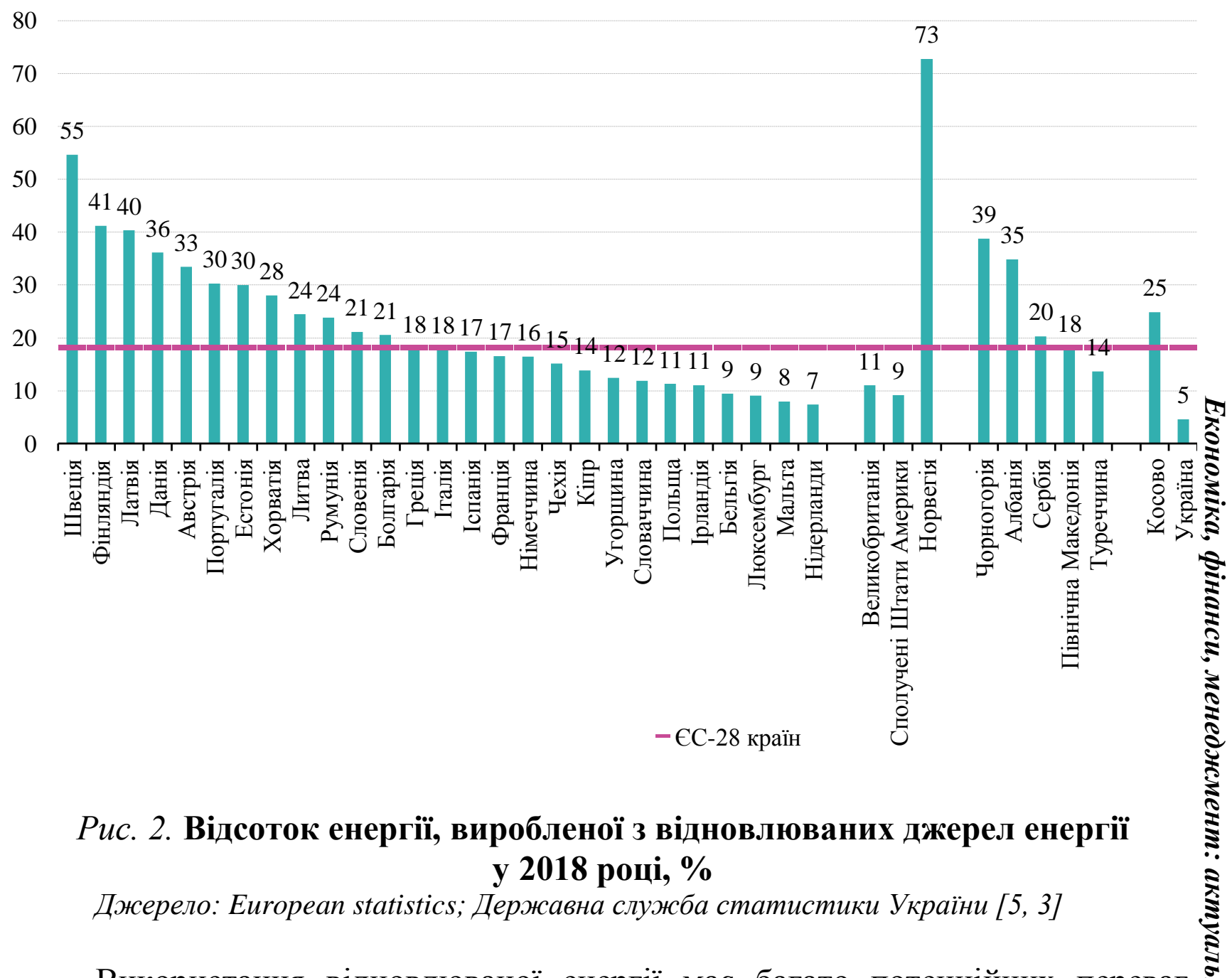

Використання відновлюваної енергії має багато потенційних переваг, 音. включаючи скорочення викидів парникових газів, диверсифікацію поставок енергії та зменшення залежності від ринків викопного палива (зокрема, нафти та газу). Зростання відновлюваних джерел енергії також може стимулювати зайнятість в СС через створення робочих місць у нових «зелених» технологіях та забезпечення енергетичної автономії господарювання в аграрному секторі за рахунок використання відходів сільськогосподарського виробництва для переробки на біопалива.

Щороку жителі більшості громад, що використовують природний газ та електроенергію для опалення та інших побутових потреб сплачують від десятків до сотень мільйонів гривень. Ці кошти майже повністю виводяться 3 місцевої економіки і йдуть на оплату газу та електрики, які постійно зростають.

За даними Державної служби статистики України, у II півріччі 2019 року : ціни на електроенергію для побутових і не побутових споживачів виросли усередньому на 0,03 грн. за 1 кВт.год, кількість побутових споживачів зросла на 228745 од., відповідно і обсяг поставленої енергії зріс на 376543 тис.кВт·год. і 
становить 16347585,1 тис.кВт·год (табл. 1). [3].

Таблиия 1

Постачання електроенергії в Україні у 2018-2019 рр.

\begin{tabular}{|c|c|c|c|}
\hline \multirow{2}{*}{ Показник } & \multicolumn{2}{|c|}{ Роки } & \multirow{2}{*}{$\begin{array}{c}\text { Відхилення, } \\
+/-\end{array}$} \\
\hline & 2018 & 2019 & \\
\hline \multicolumn{4}{|c|}{ побутові споживачі - усього } \\
\hline Кількість споживачів, од. & 16744296 & 16973041 & 228745 \\
\hline Обсяг поставленої електроенергії, тис.кВт·год & 15971042,1 & 16347585,1 & 376543 \\
\hline Середня ціна електроенергії, без ПДВ, грн за 1 кВт·год & 1,00 & 1,03 & 0,03 \\
\hline Середня ціна електроенергії, з ПДВ, грн за 1 кВт·год & 1,20 & 1,23 & 0,03 \\
\hline \multicolumn{4}{|c|}{ не побутові споживачі - усього } \\
\hline Кількість споживачів, од. & 533272 & 505812 & -27460 \\
\hline Обсяг поставленої електроенергії, тис.кВт·год & 41500391,3 & 32927552,6 & $-8572838,7$ \\
\hline Середня ціна електроенергії, без ПДВ, грн за 1 кВт·год & 1,82 & 1,85 & 0,03 \\
\hline Середня ціна електроенергії, з ПДВ, грн за 1 кВт·год & 2,19 & 2,22 & 0,03 \\
\hline
\end{tabular}

Джерело: таблиия сформована за даними Державної служби статистики України [3]

- Переспрямування такого грошового потоку постачальникам

відновлюваних джерел енергії може стати потужним стимулом розвитку จิ сільських територій, адже кошти будуть отримувати місцеві фермери та підприємці. Тому створення потужностей з виробництва пелет чи брикетів для опалення розвиває громади. Електростанції, які використовують сонячне проміння, вітер чи біомасу, теж можуть розвивати громади, особливо, сільські.

В Україні, згідно з даними Державної служби статистики України, станом на 1 січня 2020 року нараховується 42,16 млн осіб населення з них міського 29,26 млн осіб $(69,4 \%)$, сільського - 12,9 млн осіб (30,6\%), яке проживає у 686 об'єднаних територіальних громадах, 461 - в місті, 883 - у селищах міського типу, 28376 - у сільських населених пунктах. Порівнюючи дані чисельності населення України та кількість адміністративно-територіальних одиниць, спостерігаємо негативну тенденцію скорочення чисельності сільського населення та зникнення з карти України щороку від 3 до 40 сіл. Однією із причин $\epsilon$ високий рівень безробіття серед населення, яке проживає у сільській місцевості, нестача робочих місць, недостатній рівень розвитку соціальноекономічної інфраструктури. За результатами обстеження робочої сили, протягом січня-грудня 2019 року нараховується 492,9 тис. осіб безробітних працездатного віку, найбільшу частку безробітних займає населення віком від 25 до 49 років. За віковими групами, безробітне населення сільської місцевості становить: населення віком 15-24 роки - 87,8 тис.осіб, 25-29 років - 66 тис.осіб, 30-34 роки - 67,4 тис.осіб, 35-39 років - 55,1 тис.осіб, 40-49 років 108,7 тис.осіб, 50-59 років - 107,8 тис.осіб, 60-70 років - 0,1 тис.осіб.

Кількість зайнятого населення у віці 15-70 років у сільській місцевості становить 5,16 млн осіб, з них ті, які працюють за наймом - 3598,5 тис. осіб, роботодавці - 53,1 тис.осіб, самозайняті - 1,49 млн осіб, безкоштовно працюючі члени сім'ї - 24 тис.осіб. Брак робочих місць і низька зайнятість працездатного населення у сільській місцевості призводить до соціальної напруги серед населення [3]. 
Вирішити проблеми зі створенням робочих місць та зменшення тягаря оплати за енергоресурси, особливо у сільській місцевості, можна за рахунок створення енергетичних кооперативів.

Енергетичний кооператив - це об'єднання фізичних та юридичних осіб, які створили кооператив коштом власних пайових внесків. Вони управляють кооперативом та отримують прибутки від його діяльності. Незалежно від розміру паю, один член має один голос, однак прибутки розподіляються пропорційно до розмірів паїв. Енергетичний - бо працює у сфері енергоефективності та відновлюваних джерел енергії [2, с. 8].

Закон України «Про альтернативні джерела енергії» визначає енергетичний кооператив як юридичну особу, засновану відповідно до Закону України «Про кооперацію» або Закону України «Про споживчу кооперацію» для здійснення господарської діяльності 3 виробництва, заготівлі або транспортування паливно-енергетичних ресурсів, а також для надання інших послуг з метою задоволення потреб його членів або територіальної громади, а також з метою отримання прибутку, відповідно до вимог законодавства [1].

До енергетичних кооперативів належать будь-які кооперативи, що тим чиіншим чином пов'язані із забезпеченням енергією своїх членів або третіх осіб. Такі об'єднання довели свою ефективність у багатьох країнах світу, зокрема в США та країнах-членах Свросоюзу.

Згідно з доповіддю «Дослідження кооперативної економіки» за 2018 рік, підготовленою The International Cooperative Alliance (ICA) та Європейським науково-дослідним інститутом кооперативних та соціальних підприємств (EURICSE), кооперативи відіграють важливу роль у світовій економіці. Для цілей звіту були зібрані економічні та соціальні дані від 2575 кооперативних підприємств та взаємних організацій у всьому світі. Що стосується фінансових аспектів, то у звіті встановлено, що у 2016 році 300 найбільших кооперативів та пайовиків мали загальний обіг у розмірі 2018 трлн дол. США (порівняно $з 2164$ трлн дол. США у 2015 р.). Існує 3 мільйони кооперативів у всьому світі, які разом забезпечують роботою близько 280 мільйонів осіб або $10 \%$ зайнятого населення у світі.

Господарська діяльність кооперативів - різноманітна. Наприклад, у 2016 році 33\% усіх кооперативів (які брали участь в опитуванні) працювали у сільському господарстві та харчовій промисловості; $19 \%$ займалися банківськими та фінансовими послугами; 16\% - інші послуги (наприклад, бізнеспослуги, транспорт, зв'язок); 7\% - промисловість та комунальне господарство; 6\% складали страхові кооперативи та пайові товариства і 4\% працювали в секторах охорони здоров'я, освіти та соціального захисту (рис. 3) [4].

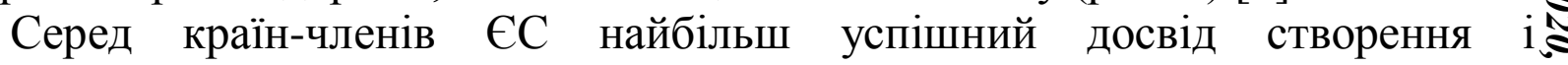
функціонування енергетичних кооперативів у Німеччині.

Місцеві громади Німеччини накопичили значний досвід у створенні енергетичних кооперативів (Energiegenossenschaften). На території країни на сьогодні діє понад тисяча різноманітних енергетичних кооперативів, що 
займаються постачанням своїм членам і третім особам цілої низки енергетичних ресурсів і послуг.

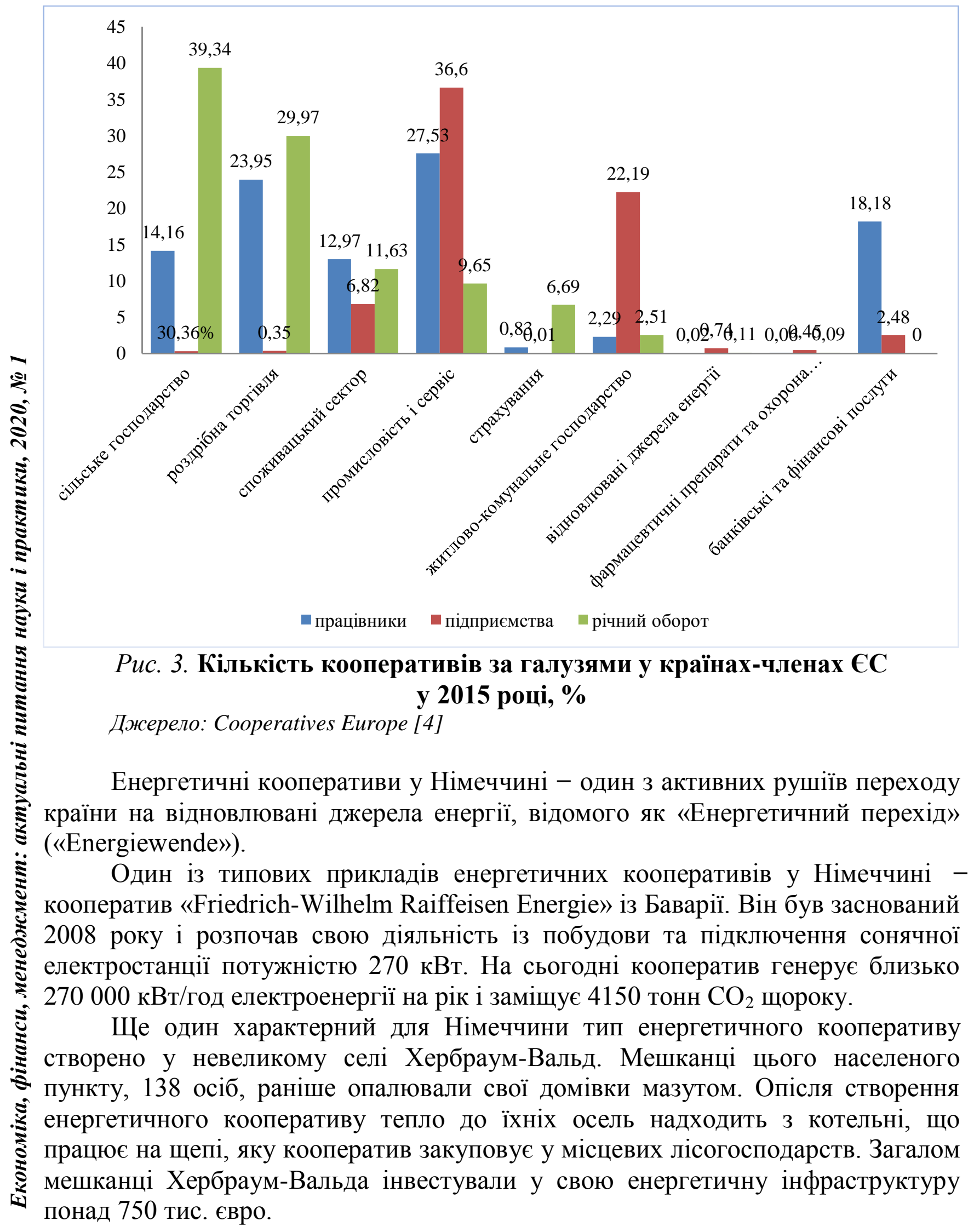


Ще один приклад ефективного використання кооперативної моделі - село Фельдгайм, розташоване на 60 кілометрів південніше Берліна (земля Бранденбург). Місцевий сільськогосподарський кооператив побудував біогазову установку. Біогазова установка виробляє 4,3 мільйона кіловат-годин тепла на рік, яким обігріваються приміщення кооперативу і будинки мешканців села. Щоб доставити тепло до кожного будинку, місцеві мешканці також проклали теплову мережу, половину вартості якої було профінансовано коштами землі Бранденбург та ЄС. Вартість мереж становила близько 1,7 мільйона євро, при цьому кожен із мешканців вклав у проєкт близько 3000 євро.

Хоча найбільшого розвитку енергетичні кооперативи набули саме у Німеччині, вони $є$ активними учасниками енергетичних ринків у багатьох країнах $\mathrm{CC}$.

Серед них особливо вирізняється Данія, Австрія, Швеція та Нідерланди. При цьому останнім часом важливість енергокооперативів і громад, що забезпечують себе енергією, для стійкого енергетичного розвитку отримує визнання на рівні ЄС. Зокрема, у нещодавно запропонованому стратегічному документі СС «Чиста енергія для всіх європейців» містяться положення щодо ролі енергетичних кооперативів у забезпеченні переходу країн $€ \mathrm{C}$ на використання відновлюваних джерел енергії [13, с. 7-9].

У США одним із найбільших гравців електроенергетичного ринку $є$ громади, що об'єдналися в енергетичні кооперативи. Усього у цій країні працює 903 кооперативи, що займаються розподілом (доставкою до кінцевого ॐ̆ споживача) електроенергії. Вони забезпечують електропостачання 42 мільйонам жителів 47 штатів. Сервісні території цих кооперативів покривають $75 \%$ території США. Усі ці мережі разом, із усім обладнанням, що до них належить, перебувають у безпосередній власності членів відповідних енергетичних кооперативів. Інакше кажучи, вони належать не компаніям, які зорієнтовані на максимізацію своїх прибутків, а безпосереднім користувачам послуг.

Енергетичні кооперативи є невід'ємною частиною електроенергетичного ринку США, що оцінюється нині у 364 млрд доларів США. Ціна їхніх активів, за даними NRECA (National Rural Electric Cooperative Association - Національна Асоціація Сільських Електричних Кооперативів), на сьогодні становить 164 млрд доларів США. Вони володіють і підтримують у робочому стані $42 \%$ від загальної кількості розподільчих ліній передачі електроенергії загальною довжиною 2,6 мільйонів миль (4,18 млн км). Сільські енергокооперативи доставляють до кінцевих споживачів 11\% усієї електроенергії, що постачається щорічно споживачам у США, а також генерують близько 5\% загальної кількості електроенергії, що виробляється у США. Вони $€$ роботодавцем для 72 тис. американців.

На сьогодні у США найпоширенішими і найчисленнішими є енергетичні 今 кооперативи, діяльність яких спрямована на генерування електроенергії та іiі розподіл кінцевим споживачам, а також на електрифікацію (переважно сільських) територій. Проте, крім них, існує велика кількість кооперативів, які 
забезпечують своїх членів найрізноманітнішими енергетичними ресурсами i послугами. Так, Piedmont Biofuels Cooperative, розташований у місті Пітсборо (штат Північна Кароліна), забезпечує своїх членів біодизелем. Дизельне паливо кооператив виробляє із відходів харчової промисловості - відпрацьованої соняшникової, арахісової, соєвої, канолової олій, а також із жиру, що виділяється при смаженні сосисок i м'яса птиці у закладах харчування. Членство у кооперативі дає змогу його учасникам економити на заправці своїх автомобілів дизельним пальним. Варто зазначити, що цей кооператив виконує також важливу соціальну функцію - переробляє відпрацьовані відходи харчової промисловості.

Ще один приклад енергетичного кооперативу в США -Evergreen Energy Solutions, що займається встановленням сонячних електростанцій у Клівленді.

Кооператив наймає на роботу насамперед місцевих мешканців, а серед його клієнтів - клівлендські клініки, госпіталь місцевого університету, Case Western Reserve University, муніципальні служби міст Клівленд й Евклід.

В Україні енергетичні кооперативи мають великі перспективи. Вони можуть дати громадам та іншим самоорганізованим групам можливість забезпечувати себе найрізноманітнішими енергетичними ресурсами - від твердого палива для обігріву окремих домівок до електроенергії для домогосподарств і бізнесів.

Дуже великі перспективи для розвитку енергокооперативів наявні у сільській місцевості, де за даними Держкомстату проживає майже 30 \% населення (близько 13,2 мільйона осіб). Для багатьох українських селян оплата енергетичних ресурсів на сьогодні $є$ значним фінансовим тягарем, особливо після останніх підвищень цін на газ і на електроенергію.

Об’єднання їх в енергетичні кооперативи дасть змогу скоротити ці витрати, наприклад завдяки використанню доступніших енергетичних ресурсів, як-от біомаси, що є одним із продуктів сільськогосподарського виробництва. За даними БАУ (Біоенергетичної Асоціації України), наша країна має значний потенціал виробництва енергії з біомаси - понад 30 мільйонів т. У. п. (тонн умовного палива) на рік. Із цього потенціалу Україна нині використовує близько $10 \%$, виробляючи із різних типів біомаси лише 3 мільйони тонн умовного палива. Проаналізувавши світовий досвід, можна виокремити такі економічні моделі енергетичних кооперативів, що можуть застосовуватись українськими громадами: виробництво палива з відходів сільського та лісового господарства; сонячна чи вітрова електростанція, яка продає електрику в мережу за підвищеним тарифом; виробництво біогазу 3 біомаси; виготовлення та використання сонячних водонагрівачів (табл. 2) [13, с.3-5].

В Україні вже з'явились перші спільноти, які застосовують модель енергетичного кооперативу, що використовує біомасу. Наприклад, жителі села Лосятин (Кременецький район Тернопільської області) на базі сільськогосподарського обслуговувального кооперативу «Ягідний край» організували переробку відходів виробництва у паливні брикети. Відходи виробництва кооперативу - стебла малини, які щоосені після закінчення сезону 
Економічні моделі енергетичних кооперативів, що можуть застосовуватись українськими громадами

\begin{tabular}{|c|c|c|c|c|}
\hline $\begin{array}{l}\text { Бюджет } \\
\text { проєкту }\end{array}$ & $\begin{array}{c}\text { Терміни } \\
\text { реалізацї̈ }\end{array}$ & $\begin{array}{l}\text { Окупність } \\
\text { інвестицій }\end{array}$ & Суть технології & Соціальні питання \\
\hline \multicolumn{5}{|c|}{ Виробництво палива з відходів сільського чи лісового господарства } \\
\hline $\begin{array}{lr}\text { від } & 30 \\
\text { тис.євро }\end{array}$ & 4 місяців & 4-6 років & 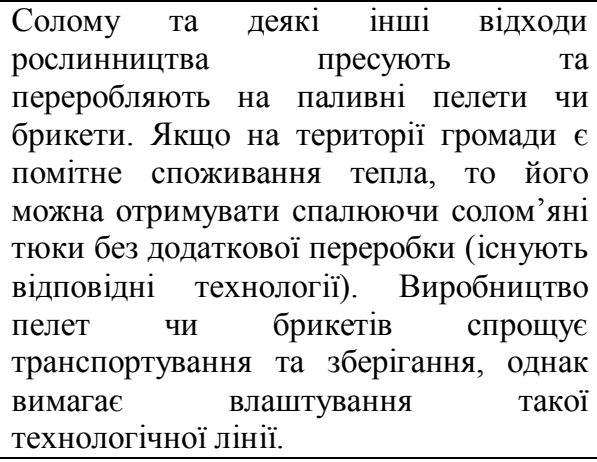 & $\begin{array}{l}\text { Громада отримує нові робочі } \\
\text { місця, податкові надходження. } \\
\text { Створення продукту } 3 \text { доданою } \\
\text { вартістю на території громади. } \\
\text { Зменшення вартості опалення } \\
\text { бюджетних та па приватних } \\
\text { помешкань порівняно } 3 \text { газом за } \\
\text { наявності твердопаливних котлів. } \\
\text { Усунення бездумного спалювання } \\
\text { соломи на полях. }\end{array}$ \\
\hline \multicolumn{5}{|c|}{ Сонячна чи вітрова електростанція, що продає електрику у мережу за підвищеним тарифом } \\
\hline $\begin{array}{lr}\text { від } 10 \\
\text { тис.євро }\end{array}$ & $\begin{array}{l}\text { 6-12 } \\
\text { місяців }\end{array}$ & 6-8 років & $\begin{array}{l}\text { Електроенергія виробляється завдяки } \\
\text { перетворенню сонячного проміння } \\
\text { панелями або генераторами, які } \\
\text { обертаються вітром. В обох випадках } \\
\text { електрика подається у мережу за } \\
\text { «еленим» тарифом. }\end{array}$ & $\begin{array}{l}\text { Громада отримує джерело чистої } \\
\text { енергії у себе на території, нові } \\
\text { робочі місця, орендну плату за } \\
\text { землю або дах будівлі, податкові } \\
\text { надходження. Залежно від } \\
\text { залученості органів місцевого } \\
\text { самоврядування до реалізації } \\
\text { проєкту можуть бути інші } \\
\text { покращені умови, наприклад, } \\
\text { частина прибутку. }\end{array}$ \\
\hline \multicolumn{5}{|c|}{ Виробництва біогазу з біомаси } \\
\hline $\begin{array}{lr}\text { від } & 30 \\
\text { тис.євро }\end{array}$ & 6 місяців & $\begin{array}{l}10-15 \\
\text { років }\end{array}$ & 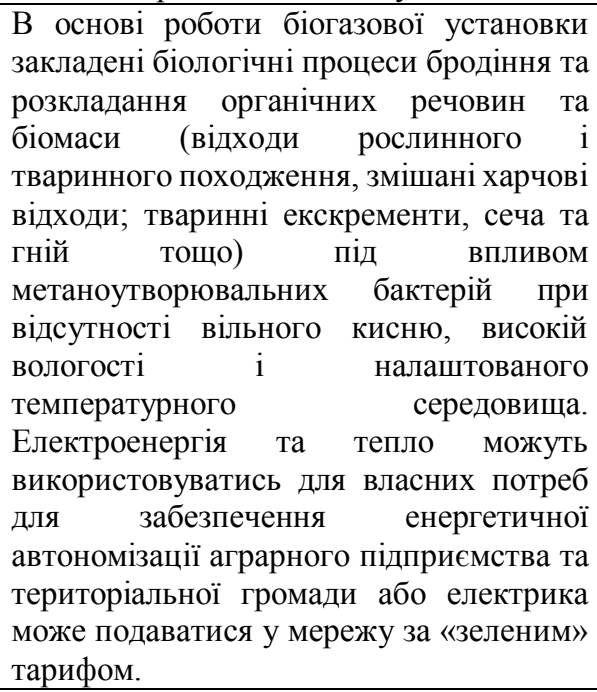 & $\begin{array}{l}\text { Громада отримує джерело чистої } \\
\text { енергії у себе на території (тепло } \\
\text { та електроенергія), нові робочі } \\
\text { місця та вирішення проблеми } \\
\text { поводження } \\
\text { сільськогосподарськими } \\
\text { відходами. } \\
\text { екологічна складова - зменшення } \\
\text { викидів забруднюючих речових у } \\
\text { повітря, воду та грунт. } \\
\text { Підвищення родючості грунту, } \\
\text { оскільки відходами біогазових } \\
\text { установок є високоякісне } \\
\text { органічне добриво (дигестат). }\end{array}$ \\
\hline \multicolumn{5}{|c|}{ Виготовлення та використання сонячних водонагрівачів } \\
\hline $\begin{array}{l}15 \\
\text { тис. грн }\end{array}$ & - & 6 років & $\begin{array}{l}\text { Сонячна енергія за допомогою прямого } \\
\text { нагріву перетворюється у } \quad \text { теплову } \\
\text { енергію. При площі збору сонячної } \\
\text { енергії } 2 \text { м² можна отримати }^{2} 100 \text { літрів } \\
\text { води } 3 \text { температурою } 55 \quad{ }^{\circ} \mathrm{C} \text {. } \\
\text { Ефективність установки залежить від } \\
\text { погодних умов, періоду року та якості } \\
\text { спорудження сонячного колектора. } \\
\text { Працює лише у весняно-осінній період. }\end{array}$ & 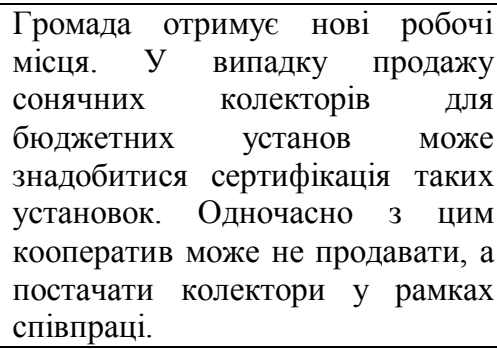 \\
\hline
\end{tabular}


Використовуючи донорські та власні кошти, члени кооперативу придбали брикетувальну установку, що перетворює стебла малини у високоякісні брикети. Вони добре підходять для опалення будинків селян - як тих, які користуються твердопаливними котлами, так і тих, хто користується грубами. Опалення такими брикетами обходиться дешевше, ніж опалення газом, і дає змогу 3 користю застосувати відходи - стебла малини, які раніше на полях просто спалювали [13, с. 11].

TOB «Берездівський енергетичний кооператив» заснований у 2018 році у Берездівській ОТГ (Хмельницька обл). Засновниками стали: приватні особи, ГО «Екоклуб» та КП «Берездів». Кооператив буде випускати паливні брикети 3 соломи, купленої у місцевих фермерів. Перед створенням кооперативу було проведено переговори 3 місцевими фермерськими господарствами (є СТОВ «Бесідки», ФГ «Обрій», ПП «Екоагролан-плюс», СФГ «Манятин») та досягнуто домовленості щодо закупівлі залишків соломи, які раніше залишалися на полях. Ці ж фермери є членами кооперативу. Усі члени кооперативу, незалежно від внеску, мають лише один голос відповідно до статуту. При цьому прибуток вони будуть отримувати залежно від частки внеску.

Потенційні споживачі: комунальні заклади Берездівської сільської ради; приватні підприємства; місцеве населення та споживачі за межами громади. На першому етапі брикети будуть використовуватися для опалення однієї зі шкіл об’єднаної територіальної громади.

Учасниками Берездівського енергетичного кооперативу можуть стати фізичні та юридичні особи, які готові внести до статутного капіталу підприємства кошти в розмірі еквівалентному не менше $500 €$ (але не менше 15 тис. грн.), або цінні папери, нерухомість чи інше майно вартістю не менше 15 тис. грн. [2, с.27].

Муніципальний енергетичний кооператив «Сонячне місто» був заснований у 2018 році у м. Славутич (Київська обл.). Членами кооперативу $\epsilon$ приватні особи та КП «Агенція регіонального розвитку» м. Славутич. Правова форма кооперативу: споживче товариство [2, с.21].

Ідеєю, яку планує реалізувати кооператив, $є$ встановлення сонячних електростанцій на дахах бюджетних та комунальних будівель, орендованих у міста. Вироблена електроенергія буде продаватися в мережу за «зеленим» тарифом. Всі охочі можуть стати членами кооперативу.

Висновки. На основі проведеного дослідження можна зробити висновок, що кооперативний досвід країн-членів СС та США у галузі енергозабезпечення може бути корисним при вирішенні цілого комплексу проблем в Україні, пов'язаних передусім із задоволенням потреб сільського населення, суб'єктів господарювання аграрного сектору електроенергією та зменшення рівня безробіття.

Перевагами від створення енергокооперативів $є$ підвищення економічної активності громади; створення доданої вартості; екологічна утилізація відходів сільського господарства; залучення інвестицій для розвитку сільських територій; 
створення додаткових робочих місць; збільшення податкових надходжень у місцеві бюджети; підвищення енергонезалежності територіальних громад та забезпечення енергетичної автономії сільськогосподарських підприємств.

\section{Список використаних джерел}

1. Про альтернативні джерела енергії : Закон України від 9 серпня 2019 p. № 555-IV. URL: http://zakon1.rada.gov.ua/laws/show/1315-18 (дата звернення: 10.04.2020).

2. Мартинюк А.М., Сакалюк Д.С., Мар'юк О.В., Холодова Н.В. Енергетичні кооперативи: енергонезалежність для громад. Київ: Громадська організація «Екоклуб». 34 с. URL: https://ua.boell.org/uk/2019/11/28/energetichnikooperativi-energo-nezalezhnist-dlya-gromad (дата звернення: 09.04.2020).

3. Державна служба статистики України. URL: http://www.ukrstat.gov.ua. (дата звернення 12.04.2020).

4. Cooperatives Europe: URL: https://coopseurope.coop/ (дата звернення 08.04.2020).

5. International Energy Agency. URL: https://www.iea.org/areas-ofwork/global-engagement (дата звернення 08.04.2020).

6. European statistics. URL: https://ec.europa.eu/eurostat/home? (дата звернення 08.04.2020).

7. Climate Action Plan 2050.

$\mathrm{URL}:$ https://unfccc.int/files/focus/application/pdf/161114_climate_action_plan_2050.pdf (дата звернення 12.04.2020).

8. Кузьміна М. Правове регулювання створення та функціонування енергетичних кооперативів в Україні. Підприємництво, господарство і право. 2019. № 7. C. 40-44. DOI: $10.32849 / 2663-5313.2019 .7 .7$

9. Шпикуляк О.Г., Іванченко В.О. Досвід Німеччини у розвитку енергетичних кооперативів: перспективи для України. Економіка АПК. 2018. № 8. C. 92-101.

10. Байко Р. Енергетичні кооперативи: досвід Німеччини та Австрії: довідник. Київ : Офіс з фінансового та економічного аналізу у Верховній Раді України, 2016. 32 c. URL: https://feao.org.ua/wpcontent/uploads/2017/02/FEAO_Energy_cooperatives.pdf (дата звернення: 09.04.2020).

11. Коссе I. Історії успіху реформ. Київ: Інститут економічних досліджень та політичних консультацій, 2019. 260 с. URL: https://rpr.org.ua/wpcontent/uploads/2020/02/rfr_success_stories_book_ua.pdf (дата звернення: 09.04.2020).

12. Wierling, A.; Schwanitz, V.J.; Zeiß, J.P.; Bout, C.; Candelise, C.; Gilcrease, : W.; Gregg, J.S. Statistical Evidence on the Role of Energy Cooperatives for the Energy Transition in European Countries. Sustainability. 2018, 10, 3339. DOI:10.3390/su10093339

13. Зінченко А., Скляров Р., Бондарчук I. Енергетика спільнот: як 
енергетичні кооперативи сприяють стійкості громад по всьому світу : довідник. Київ: Центр Економічної Демократії, 2018. 13 с.

14. Гончарук I.В. Роль сільськогосподарських кооперативів у забезпеченні сталого розвитку сільських територій Вінницької області. Економіка, фінанси, менеджмент: актуальні питання науки і практики. 2017. №8(24). С. 56-67.

15. Калетнік Г.М., Гончарук І.В. Складові розвитку сільських територій та моделі аграрного підприємництва і кооперації. Розвиток малого і середнього підприємництва та кооперації на селі. Проблеми та перспективи: зб. матеріалів наук. конф. і навч.-практ. семінару. Вінниця : Едельвейс і К, 2015. С. 5-13.

16. Калетнік Г.М., Гончарук Т.В. Інноваційне забезпечення розвитку біопаливної галузі: світовий та вітчизняний досвід. Бізнес Інформ. 2013. № 9. C. $155-160$.

17. Оцінка вразливості до зміни клімату: Україна. URL: http://climategroup.org.ua/?p=2844.

\section{References}

1. Pro alternatyvni dzherela enerhii : Zakon Ukrainy vid 9 serpnia $2019 r$. № 555-IV [On alternative energy sources: Law of Ukraine of August 9, 2019 No. 555IV]. Retrieved from http://zakon1.rada.gov.ua/laws/show/1315-18 (data zvernennia: 10.04.2020) [in Ukrainian].

2. Martyniuk, A.M., Sakaliuk, D.S., Mariuk, O.V. \& Kholodova, N.V. Enerhetychni kooperatyvy: enerhonezalezhnist dlia hromad [Energy cooperatives: energy independence for communities]. Kyiv: Hromadska orhanizatsiia «Ekoklub», 34. Retrieved from https://ua.boell.org/uk/2019/11/28/energetichni-kooperativienergo-nezalezhnist-dlya-gromad (data zvernennia: 09.04.2020) [in Ukrainian].

3. Derzhavna sluzhba statystyky Ukrainy [State Statistics Service of Ukraine]. Retrieved from http://www.ukrstat.gov.ua (data zvernennia 12.04.2020) [in Ukrainian].

4. Cooperatives Europe. Retrieved from https://coopseurope.coop/ (data zvernennia 08.04.2020) [in Ukrainian].

5. International Energy Agency. Retrieved from https://www.iea.org/areas-ofwork/global-engagement (data zvernennia 08.04.2020) [in Ukrainian].

6. European statistics. Retrieved from https://ec.europa.eu/eurostat/home? (data zvernennia 08.04.2020) [in Ukrainian].

7. Climate Action Plan 2050. Retrieved from https://unfccc.int/files/focus/application/pdf/161114_climate_action_plan_2050.pdf (data zvernennia 12.04.2020) [in Ukrainian].

8. Kuzmina, M. (2019). Pravove rehuliuvannia stvorennia ta funktsionuvannia enerhetychnykh kooperatyviv v Ukraini [Legal regulation of creation and functioning of energy cooperatives in Ukraine]. Pidpryiemnytstvo, hospodarstvo i pravo Entrepreneurship, economy and law, 7, 40-44. Retrieved from DOI: 10.32849/26635313.2019.7.7 [in Ukrainian].

9. Shpykuliak, O.H. \& Ivanchenko V.O. (2018). Dosvid Nimechchyny u 
rozvytku enerhetychnykh kooperatyviv: perspektyvy dlia Ukrainy [Germany's experience in the development of energy cooperatives: prospects for Ukraine]. Ekonomika APK - APK economy, 8, 92-101. Retrieved from http://repository.vsau.org/getfile.php/18921.pdf [in Ukrainian].

10. Baiko, R. (2016). Enerhetychni kooperatyvy: dosvid Nimechchyny ta Avstrii: dovidnyk [Energy cooperatives: German and Austrian experience: handbook]. Kyiv : Ofis $\mathrm{z}$ finansovoho ta ekonomichnoho analizu u Verkhovnii Radi Ukrainy, 32. Retrieved from https://feao.org.ua/wpcontent/uploads/2017/02/FEAO_Energy_cooperatives.pdf (data zvernennia: 09.04.2020) [in Ukrainian].

11. Kosse, I. (2019). Istorii uspikhu reform [Success stories of reforms]. Kyiv: Instytut ekonomichnykh doslidzhen ta politychnykh konsultatsii, 260. Retrieved from https://rpr.org.ua/wp-content/uploads/2020/02/rfr_success_stories_book_ua.pdf (data zvernennia: 09.04.2020) [in Ukrainian].

12. Wierling, A., Schwanitz, V.J., Zeiß, J.P., Bout, C., Candelise, C., Gilcrease, W. \& Gregg, J.S. (2018). Statistical Evidence on the Role of Energy Cooperatives for the Energy Transition in European Countries. Sustainability, 10(9), 3339. Retrieved from DOI:10.3390/su10093339 [in Switzerland].

13. Zinchenko, A., Skliarov, R. \& Bondarchuk, I. (2018). Enerhetyka spilnot: yak enerhetychni kooperatyvy spryiaiut stiikosti hromad po vsomu svitu : dovidnyk [Community energy: how energy cooperatives contribute to community sustainability worldwide : handbook]. Kyiv: Tsentr Ekonomichnoi Demokratii, 13.

14. Honcharuk, I.V. (2017). Rol silskohospodarskykh kooperatyviv u zabezpechenni staloho rozvytku silskykh terytorii Vinnytskoi oblasti [Role of agricultural cooperatives in providing sustainable development of rural areas of Vinnytsia region]. Ekonomika, finansy, menedzhment - Economy, finances, management, $\quad 8(24), \quad 56-67 . \quad$ Retrieved http://repository.vsau.org/getfile.php/15769.pdf [in Ukrainian]. from

15. Kaletnik, H.M., \& Honcharuk, I.V. (2015). Skladovi rozvytku silskykh terytorii ta modeli ahrarnoho pidpryiemnytstva i kooperatsii [Components of rural development and models of agricultural entrepreneurship and cooperation]. Rozvytok maloho i serednoho pidpryiemnytstva ta kooperatsii na seli. Problemy ta perspektyvy: $z b$. materialiv nauk. konf. $i$ navch.-prakt. seminaru - Development of small and medium-sized enterprises and rural cooperatives. Problems and Prospects: collect. mat. science. conf. and navch.-pract. semin. Vinnytsia : Edelveis i K, 5-13. [in Ukrainian].

16. Kaletnik, H.M., \& Honcharuk, T.V. (2013). Innovatsiine zabezpechennia rozvytku biopalyvnoi haluzi: svitovyi ta vitchyznianyi dosvid [Innovative support for the development of the biofuels industry: world and national experience]. Biznes Inform - Business Inform, 9, 155-160. [in Ukrainian].

17. Otsinka vrazlyvosti do zminy klimatu [Climate change vulnerability assessment]. Ukraina. Retrieved from http://climategroup.org.ua/?p=2844 [in Ukrainian]. 


\section{Відомості про автора}

ГОНЧАРУК Інна Вікторівна - кандидат економічних наук, доцент кафедри економіки, проректор з наукової та інноваційної діяльності Вінницького національного аграрного університету (вул. Сонячна, 3, м. Вінниця, 21008, еmail: vnaunauka2019@gmail.com).

HONCHARUK Inna - PhD in Economics, Associate Professor, Department of Economics, Vice-Rector for Science and Innovation Activity, Vinnytsia National Agrarian University (21008, Vinnytsia, 3 Soniachna st, e-mail: vnaunauka2019@gmail.com).

ГОНЧАРУК Инна Викторовна - кандидат экономических наук, доцент кафедры экономики, проректор с научной и инновационной деятельности Винницкого национального аграрного университета (ул. Солнечная, 3, г. Винница, 21008, vnaunauka2019@gmail.com).

ФОРМУВАННЯ КРИТЕРIÏB TA ІНДИКАТОРІВ ОЦІНКИ РІВНЯ ЕКОЛОГІЧНОЇ БЕЗПЕКИ РЕГІОНІВ УКРАЇНИ ${ }^{3}$
ЛУТКОВСЬКА С. М. кандидат педагогічних наук, проректор з науково-педагогічної роботи, євроінтеграції та міжнародної діяльності, доцент кафедри адміністративного менеджменту та альтернативних джерел енерхії Вінницький національний аграрний університет (м. Вінниця)

У статті розглянуто методичний підхід до порівняльної очінки регіонів держави за рівнем екологічної безпеки. Запропоновано систему показників, які характеризують стан екологічної безпеки у регіональному вимірі. Доведено, щуо оцінку екологічного ризику вважають найбільш перспективним підходом до визначення ступеня екологічної небезпеки території. Концепція такої оцінки практично у всіх краӥнах світу і міжнародних організаціях розглядається як головний механізм розробки та ухвалення управлінських рішень з охорони навколишнього природного середовища. При аналізі наявних методичних розробок встановлено, щзо оичнка екологічної небезпеки базується на кількох основних підходах. Найбільш використовуваними є індикаторний, щуо спирається на систему обраних індикаторів (або індикативний метод). Установлено, щзо рівень екологічної безпеки є досить широким, оскільки потребує урахування всіх складових и̧ього прочесу: від обчислення рівня

${ }^{3}$ ЛУТКОВСЬКА С.М., 2020 